Original Article

\title{
Knowledge on Health Consequences of Early and Late Marriage among Students at Selected College, East Sikkim
}

\author{
Arkierupaia Shadap ${ }^{1}$, Thoibi Devi ${ }^{2}$, Anjana Sharma ${ }^{3}$, Anu Sapkota ${ }^{4}$, Yamuna Sharma ${ }^{5}$, Srijana \\ Basnett ${ }^{6}$, Ashma Sharma ${ }^{7}$, Binita Thapa ${ }^{8}$, Kesang Bhutia ${ }^{9}$, Pema D. Bhutia ${ }^{10}$, Karma Doma Bhutia ${ }^{11}$, \\ Tashi Lamu Bhutia ${ }^{12}$, Passang Kee Bhutia ${ }^{13}$, Sunita Subba ${ }^{14}$, Karishma Rai $^{15}$, Passang Dikki Sherpa ${ }^{16}$
}

\begin{abstract}
${ }^{1}$ Assistant Professor, ${ }^{2}$ Associate Professor, $3,4,5,6,7,8,9,10,11,12,13,14,15,16$, B.Sc Nursing Students, Sikkim Manipal College of Nursing, Sikkim Manipal University.

Corresponding Author: Arkierupaia Shadap, Assistant Professor, Sikkim M anipal College of Nursing, Sikkim Manipal University. Mobile : +91 84361 49397, E-mail : shadaparkierupaia@gmail.com.

$\begin{array}{ll}\text { Received } & : 26.10 .2017 \\ \text { Review Completed } & : 28.12 .2017 \\ \text { Accepted } & : 05.01 .2018\end{array}$

Keywords : Knowledge, early marriage, late marriage, health consequences,

Abstract

M arriage is the blending together of two lives, two personalities of the opposite sex for as long as two shall live in this world. It is the building law of God and protects the mankind. But early and late marriage may have an adverse health consequence. A study was conducted to assess the knowledge on health consequences of early and late marriage among students at selected college of Sikkim. Investigators adopted the quantitative approach using the descriptive survey research design through convenient sampling technique. Structured knowledge questionnaire on health consequences of early and late marriage were developed and sent for validation to experts before collecting the data. Result shows that majority $84 \%$ and $49 \%$ has moderate knowledge, $12 \%$ and $47 \%$ has poor knowledge and $4 \%$ each has good knowledge on health consequences of early and late marriage respectively. The study reveals that there was no significant association of knowledge on health consequences of early and late marriage.
\end{abstract}

\begin{tabular}{|c|}
\hline Access this article online \\
\hline Quick Response Code \\
\hline
\end{tabular}

\section{Introduction}

Marriage is defined as "the blending together of two lives, two personalities of the opposite sex for as long as two shall live in this world. It is the building law of God and protects the mankind. Health consequences are defined as a health which has the opposite effect causing or contributing to ill health. ${ }^{1}$ Early marriage by UNICEF is defined by "a formal marriage or union before 18 years of age". The effect of early marriage may lead to the occurrences of physiological and psychological stress, denial of freedom and personal development, denial of education. ${ }^{2}$ Late pregnancy is defined as pregnancy above 35 years of age. Late marriage naturally results late pregnancy. It results in complications which affectthe health of mother as well as babies; such as difficulty in conceiving, pre-eclampsia, risk for miscarriages, the chances of fetus having genetic defect and still births. So women should be aware about ideal time of marriage and pregnancy. ${ }^{3}$

A study at Ludhania shows the effectiveness of health education in improving knowledge of urban mothers about relationship between early and late marriage and pregnancy with increased risk. The researcher concluded that further study needed to be done among large sample. ${ }^{4} \mathrm{~A}$ hospital baased cohort study was undertaken on rural hospital in west Bengal by Bharati Banerjee, G.K Pandey, Debashis Dutt, Bhaswati Sengupta, Maitraeyi $M$ andal, Sila Deb to assess the magnitude of the problem ofteenage pregnancy and its complication among teenage mothers between 15-19 years old and control cohort of mother between 20-24 years old. Teenage pregnancy compromised $24.17 \%$ of total pregnancies. Study shows that anemia, preterm delivery and low birth weight were 
more prevalence among teenager than among women who were $20-24$ years old. ${ }^{5}$

The practice of marrying girls at young age is quite common in many part of the world. In developing countries like India, adolescent motherhood is associated with early marriage as a consequence of early initiation of sexual activity. Early marriage often takes place even before the girl has attained puberty.Pregnancy before 18 years leads to many health risks. Teenagers have high rate of mortality in pregnancy or child birth than women aged 20-24 years.Globally, it shows that about $50 \%$ of miscarriage occurs for mothers who are over 45 years and rate of caesareans are about $40 \%$ high in older mothers compared to younger. Late marriage and low infertility rates tend to be closely linked. World report shows in Myanmar and South Korea having lowest rate of fertility in world because of delayed marriage. ${ }^{6}$

The prevalence rate estimated that, about 67 million women around the world had been married before the age of 18 in 2010.'International agreements affirm that students have a right to know about information regarding reproductive health, accurate timing of marriage, and child bearing. Students receive most of this information from peers which often leads to misinformation. So they need structured formal and informal learning packages for better future. ${ }^{7}$ From the reviews and present statistics, it has been found that early and late marriage leads to many complications. Therefore the investigators felt that there is a need to conduct a study in order to develop appropriate knowledge on health consequences of early and late marriage among the college students with a view to develop an informational leaflet.

\section{Methods}

A descriptive survey study design was conducted among 100 management students at ICFAI College, Gangtok; East Sikkim.The investigators adopted a convenient sampling technique. After thorough review of literatures and discussion with experts, toolwhich consists of Section 1: Demographic variables and Section 1A: Structured knowledge questionnaires on health consequences of early marriage and Section 1B: Structured knowledge questionnaires on health consequences of late marriagewere developed and sent for validation to experts. Pretesting and reliability of the tool was done and found to be reliable i.e; $r=0.8$. The data was collected after taking prior administrative permission and consent from the participants. A pilot study was conducted in order to determine the feasibility and practicability of the final study and it was found to be feasible. The data collection for the final study was done during the December'13January' 14 . The analysis of the data was done according to the objectives of the study using the descriptive and inferential statistics.

\section{Findings}

The study findings in table 1 , shows that majority $81 \%$ belonged to age group of $19-23$ years, $46 \%$ were male and $54 \%$ were female, majority $93 \%$ of student were unmarried, majority $48 \%$ of the participant were Buddhist, majority $73 \%$ were $3^{\text {rd }}$ year management students, majority $49 \%$ of participants belonged to joint family, majority $47 \%$ of participants parents had skilled occupation, $34 \%$ of participant's parents had monthly income between Rs.15001-25000, $84 \%$ of the participant did not have family history of early marriage, $90 \%$ of participants did not have family history of late marriage. Majority $50 \%$ of participants had knowledge related to early marriage through family members and relatives, $40 \%$ had knowledge related to late marriage through family membersand relatives.

Figure 1 shows that majority $84 \%$ of students has moderate knowledge, $12 \%$ has good knowledge and $4 \%$ has poor knowledge on health consequences of early marriage.

Figure 2 shows that majority $49 \%$ of students has moderate knowledge, $47 \%$ has good knowledge and $4 \%$ has poor knowledge on health consequences of late marriage.

The data in the table 2 shows that there is no association between knowledge on health consequences of early marriage with selected demographic variables.

The data in the table 3 shows that there is no association 
between knowledge on health consequences of early marriage with selected demographic variables.

Table 1 : Frequency and Percentage distribution of demographic characteristics $(\mathrm{N}=100)$

\begin{tabular}{|c|c|c|c|}
\hline SL & Demographic variables & Frequency & Percentage (\%) \\
\hline \multirow[t]{4}{*}{1} & Age (in years) & & \\
\hline & $19-23$ & 81 & 81 \\
\hline & $24-28$ & 14 & 14 \\
\hline & $29-33$ & 5 & 5 \\
\hline \multirow[t]{3}{*}{2} & Gender & & \\
\hline & Female & 46 & 54 \\
\hline & Male & 46 & 54 \\
\hline \multirow[t]{5}{*}{3} & Religion & & \\
\hline & Buddhist & 48 & 48 \\
\hline & Christian & 11 & 11 \\
\hline & Hindu & 39 & 39 \\
\hline & Muslim & 2 & 2 \\
\hline \multirow[t]{3}{*}{4} & M arital status & & \\
\hline & Married & 7 & 93 \\
\hline & Unmarried & 7 & 93 \\
\hline \multirow[t]{3}{*}{5} & Education & & \\
\hline & $2^{\text {nd }}$ Year BBA & 27 & 73 \\
\hline & $3^{\text {rd }}$ Year BBA & 27 & 73 \\
\hline \multirow[t]{4}{*}{6} & Type of family & & \\
\hline & Extended & 26 & 26 \\
\hline & Joint & 49 & 49 \\
\hline & Nuclear & 25 & 25 \\
\hline \multirow[t]{5}{*}{7} & Parent'soccupation & & \\
\hline & Government job & 33 & 33 \\
\hline & Private job & 10 & 10 \\
\hline & Skilled & 47 & 47 \\
\hline & Professional & 10 & 10 \\
\hline \multirow[t]{5}{*}{8} & \multicolumn{3}{|l|}{ M onthly income of family (in Rs) } \\
\hline & $\leq 5001$ & 9 & 9 \\
\hline & $5001-15000$ & 26 & 26 \\
\hline & $15001-25000$ & 34 & 34 \\
\hline & $\geq 25001$ & 31 & 31 \\
\hline \multirow[t]{3}{*}{9} & \multicolumn{3}{|l|}{ Family history of early marriage } \\
\hline & No & 84 & 84 \\
\hline & Yes & 16 & 16 \\
\hline \multirow[t]{7}{*}{10} & \multicolumn{3}{|c|}{$\begin{array}{l}\text { Source of information related to early marriage and its } \\
\text { health consequences (mostly heard) }\end{array}$} \\
\hline & Family members and relative & 50 & 50 \\
\hline & Friends & 11 & 11 \\
\hline & Health workers & 12 & 12 \\
\hline & Newspaper & 07 & 07 \\
\hline & Television & 03 & 03 \\
\hline & Radio & 17 & 17 \\
\hline \multirow[t]{3}{*}{11} & \multicolumn{3}{|l|}{ Family history of late marriage } \\
\hline & No & 90 & 90 \\
\hline & Yes & 10 & 10 \\
\hline
\end{tabular}

\begin{tabular}{l|l|l|l|} 
SL & Demographic variables & Frequency & Percentage (\%)
\end{tabular}

12 Source of information related to early marriage and its health consequences (mostly heard)

\begin{tabular}{ll|l} 
Family members and relative & 40 & 40
\end{tabular}

Friends

Health workers

23

Newspaper

Televesion

Radio

23

17

13

01

06

Table 2: Association between knowledge on health consequences of early marriage with the selected demographic variables.

$(\mathrm{N}=100)$

\begin{tabular}{|c|c|c|c|c|c|c|}
\hline \multirow{2}{*}{$\begin{array}{l}\text { Demographic } \\
\text { Variables }\end{array}$} & \multicolumn{2}{|c|}{ Knowledge score } & \multirow{2}{*}{\begin{tabular}{|c|} 
Chi- \\
square
\end{tabular}} & \multirow[t]{2}{*}{$d f$} & \multirow{2}{*}{$\begin{array}{l}\text { Table } \\
\text { value }\end{array}$} & \multirow[t]{2}{*}{ Remarks } \\
\hline & $\triangleleft$ Median & $\geq$ M edian & & & & \\
\hline \multicolumn{7}{|l|}{ Age (in years) } \\
\hline $19-23$ & 36 & 45 & 0.51 & 2 & 5.99 & NS \\
\hline $24-28$ & 2 & 2 & & & & \\
\hline $29-33$ & 2 & 3 & & & & \\
\hline \multicolumn{7}{|l|}{ Gender } \\
\hline Male & 19 & 27 & 0.01 & 1 & 3.89 & NS \\
\hline Female & 21 & 33 & & & & \\
\hline \multicolumn{7}{|l|}{ Religion } \\
\hline Buddhist & 20 & 25 & 0.07 & 3 & 4.82 & NS \\
\hline Christian & 5 & 5 & & & & \\
\hline Hinduism & 14 & 20 & & & & \\
\hline Muslim & 1 & 10 & & & & \\
\hline \multicolumn{7}{|l|}{ M arital status } \\
\hline Married & 4 & 3 & 0.05 & 1 & 3.84 & NS \\
\hline Unmarried & 36 & 57 & & & & \\
\hline \multicolumn{7}{|l|}{ Education } \\
\hline $2^{\text {nd }}$ Year BBA & 11 & 16 & 0.006 & 1 & 3.84 & NS \\
\hline $3^{\text {rd }}$ Year BBA & 29 & 44 & & & & \\
\hline \multicolumn{7}{|l|}{ Type of family } \\
\hline Extended & 11 & 15 & 0.03 & 2 & 5.99 & NS \\
\hline Joint & 20 & 29 & & & & \\
\hline Nuclear & 9 & 16 & & & & \\
\hline \multicolumn{2}{|c|}{ Parent's occupation } & & & & & \\
\hline \multicolumn{2}{|c|}{ Government job12 } & 21 & 0.09 & 3 & 7.82 & NS \\
\hline Private job & 3 & 7 & & & & \\
\hline Skilled & 20 & 27 & & & & \\
\hline Professional & 5 & 5 & & & & \\
\hline \multicolumn{3}{|c|}{ M onthly income of family (in Rs) } & & & & \\
\hline$\leq 5000$ & 2 & 7 & 0.51 & 3 & 7.82 & NS \\
\hline $5001-15000$ & 9 & 17 & & & & \\
\hline $15001-25000$ & 18 & 16 & & & & \\
\hline$\geq 25001$ & 11 & 20 & & & & \\
\hline \multicolumn{3}{|c|}{ Family history of early marriage } & & & & \\
\hline No & 29 & 55 & 0.86 & 1 & 3.84 & NS \\
\hline Yes & 11 & 05 & & & & \\
\hline
\end{tabular}

Source of information related to early marriage and its health consequences (mostly heard)

Family members/Friends

\begin{tabular}{|c|c|c|c|c|c|c} 
& 25 & 36 & 0.02 & 2 & 5.99 & NS \\
Health workers 4 & 8 & & & & \\
Media & 11 & 16 & & & &
\end{tabular}

$\mathrm{p}<0.05$ (level of significant) 
Table 3: Association between knowledge on health consequences of late marriage with the selected demographic variables.

$(\mathrm{N}=100)$

\begin{tabular}{|c|c|c|c|c|c|c|}
\hline \multirow{2}{*}{$\begin{array}{l}\text { Demographic } \\
\text { Variables }\end{array}$} & \multicolumn{2}{|c|}{ Knowledge score } & \multirow{2}{*}{\begin{tabular}{|c} 
Chi- \\
square
\end{tabular}} & \multirow[t]{2}{*}{ df } & \multirow{2}{*}{$\begin{array}{l}\text { Table } \\
\text { value }\end{array}$} & \multirow[t]{2}{*}{ Remarks } \\
\hline & $\triangleleft$ Median & $\geq$ M edian & & & & \\
\hline \multicolumn{7}{|c|}{\begin{tabular}{|l|l|l|} 
Age (in years) & & \\
\end{tabular}} \\
\hline $19-23$ & 37 & 44 & 0.06 & 2 & 5.99 & NS \\
\hline $24-28$ & 8 & 6 & & & & \\
\hline $29-33$ & 2 & 3 & & & & \\
\hline \multicolumn{7}{|l|}{ Gender } \\
\hline Male & 21 & 25 & 0.015 & 1 & 3.84 & NS \\
\hline Female & 26 & 28 & & & & \\
\hline \multicolumn{7}{|l|}{ Religion } \\
\hline Buddhist & 22 & 26 & 0.015 & 3 & 7.82 & NS \\
\hline Christian & 5 & 6 & & & & \\
\hline Hinduism & 19 & 20 & & & & \\
\hline Muslim & 1 & 1 & & & & \\
\hline \multicolumn{7}{|l|}{ M arital status } \\
\hline Married & 3 & 7 & 0.003 & 1 & 3.84 & NS \\
\hline Unmarried & 44 & 49 & & & & \\
\hline \multicolumn{7}{|l|}{ Education } \\
\hline $2^{\text {nd }}$ Year BBA & 12 & 15 & 0.019 & 1 & 3.84 & NS \\
\hline $3^{\text {rd }}$ Year BBA & 35 & 38 & & & & \\
\hline \multicolumn{7}{|l|}{ Type of family } \\
\hline Extended & 13 & 13 & 0.24 & 2 & 5.99 & NS \\
\hline Joint & 25 & 24 & & & & \\
\hline Nuclear & 9 & 16 & & & & \\
\hline \multicolumn{7}{|c|}{ Parent's occupation } \\
\hline \multicolumn{2}{|c|}{ Government job14 } & 19 & 0.75 & 3 & 7.82 & NS \\
\hline Private job & 5 & 5 & & & & \\
\hline Skilled & 20 & 27 & & & & \\
\hline Professional & 5 & 5 & & & & \\
\hline \multicolumn{7}{|c|}{ M onthly income of family (in Rs) } \\
\hline$\leq 5000$ & 3 & 6 & 0.17 & 3 & 7.82 & NS \\
\hline $5001-15000$ & 13 & 13 & & & & \\
\hline $15001-25000$ & 3 & 6 & & & & \\
\hline$\geq 25001$ & 13 & 18 & & & & \\
\hline \multicolumn{3}{|c|}{ Family history of late marriage } & & & & \\
\hline No & 39 & 51 & 0.84 & 1 & 3.84 & NS \\
\hline Yes & 08 & 02 & & & & \\
\hline
\end{tabular}

Source of information related to late marriage and its health consequences(mostly heard)

Family members/Friends

\begin{tabular}{|c|c|c|c|c|c|c|}
\hline \multicolumn{7}{|c|}{ 然 } \\
\hline & 35 & 28 & 1.16 & 2 & 5.99 & NS \\
\hline Health & s 8 & 9 & & & & \\
\hline Media & 416 & & & & & \\
\hline
\end{tabular}

$p \triangleleft 0.05$ (level of significant)
Figure 1 : Cone diagram of knowledge score on health consequences of early marriage

$(\mathrm{N}=100)$

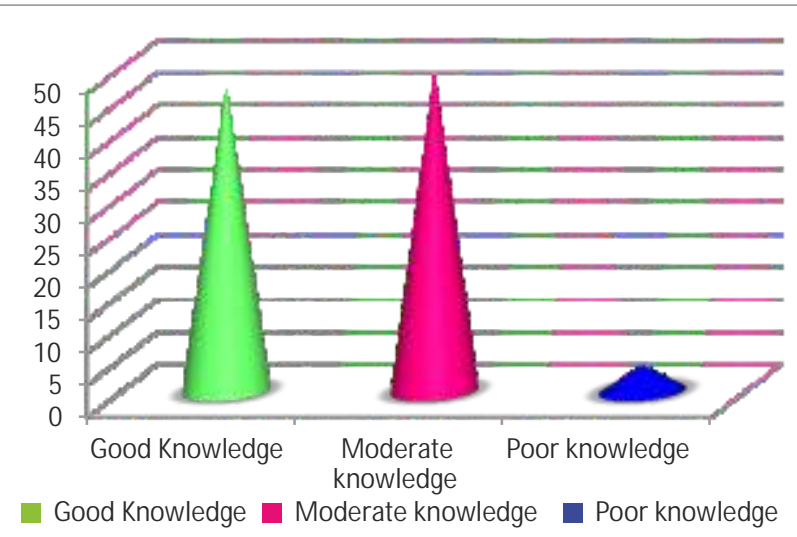

Figure 2 : Pie diagram of knowledge score on health consequences of late marriage

$(\mathrm{N}=100)$

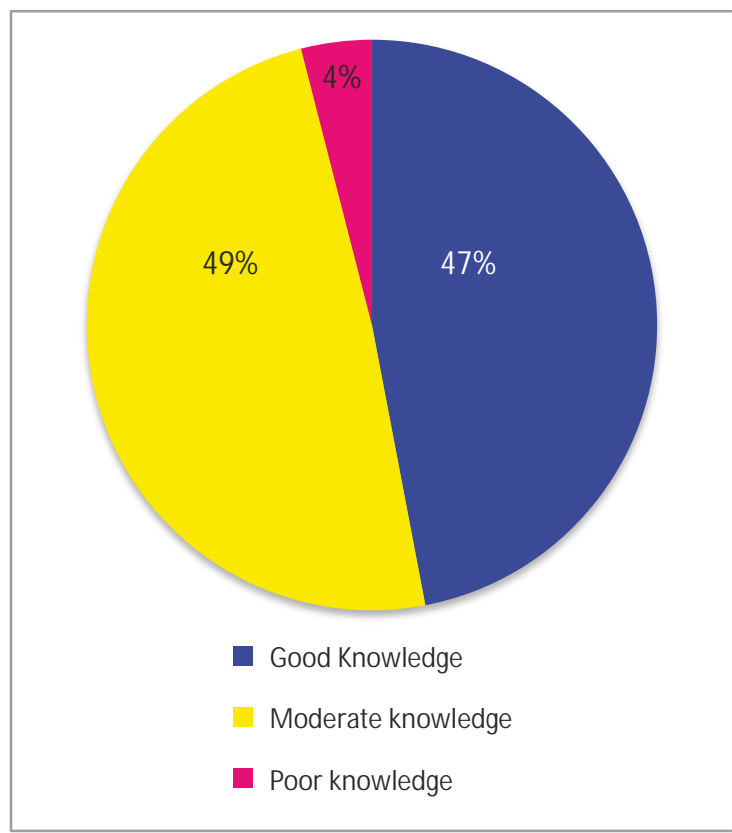

\section{Discussion}

The present study shows that majority $47 \%$ has poor knowledge on health consequences of late marriage, which was supported by a study conducted on delayed child bearing and its complication in United Kingdom where majority $40 \%$ has poor knowledge.

\section{Conclusion}

The present study reveals, majority $84 \%$ and $49 \%$ of the college students have moderate knowledge on health consequences of early and late marriage respectively. Adolescents and college students are the future of the society and it is important for them to be aware about the 
health consequences of early and late marriage. So, as health care professional we play an important role in disseminating information on health consequences of early and late marriage so as to improve the health and decrease the morbidity and mortality rate.

\section{References}

1. http://www.unicef.org/protection/index marriage.html

2. Early marriage problems, causes, harmful effects. http://marriage.com

3. Dutta's DC. Textbook of obstetrics. $7^{\text {th }}$ edition, New Central Book Agency(P) Ltd.

4. Joseph Neethu. Effectiveness of Structured teaching programme on knowledge regarding health consequences of early and late marriage among adolescent girls at tumkur. 2010; M ay. Page no:481-484

5. Bratati Banerjee et al, teenage pregnancy. A socially inflicted health hazard. Journal of community medicine. Volume 34(3); July 2009.

6. Information regarding reproductive health education among rural adolescent girls.A school based intervention; Karnataka 2008. Volume 62. Issue 11. Page no: 439-443

7. International Conference on population and development; Cairo.1995. May.

\section{Acknowledgement}

The authors would like to thank the Principal, Sikkim Manipal College of Nursing and the participants for their contribution and cooperation, without which the study would not have been completed. 